\title{
PENGARUH PENGGUNAAN FILLER YANG BERBEDA TERHADAP NILAI pH, KADAR AIR, CITARASA DAN KEKENYALAN BAKSO DAGING SAPI
}

\author{
Esterlita E. Sepang, C.K.M. Palar, M. Sompie* dan G.D.G. Rembet
}

Fakultas Peternakan Universitas Sam Ratulangi Manado 95115

\begin{abstract}
ABSTRAK
Penelitian ini bertujuan untuk mengetahui pengaruh perbedaan jenis filler terhadap nilai $\mathrm{pH}$, kadar air, citarasa dan kekenyalan bakso daging sapi. Penelitian ini menggunakan Rancangan Acak Lengkap (RAL) 4 x 4 dengan perlakuan perbedaan jenis filler dengan konsentrasi filler $15 \%(\mathrm{R})$ : $\mathrm{R}_{1}=$ tepung tapioka, $\mathrm{R}_{2}=$ tepung sagu sagu, $\mathrm{R}_{3}=$ tepung jagung, $\mathrm{R} 4=$ tepung terigu. Masing-masing perlakuan diulang sebanyak empat kali. Variabel yang di analisis pada penelitian ini adalah: nilai $\mathrm{pH}$, kadar air, citarasa dan kekenyalan. Jika ada perbedaan nyata antara perlakuan dilanjutkan dengan uji Beda Nyata Jujur. Hasil penelitian menunjukkan bahwa bahan pengisi masingmasing tepung pada daging sapi memberikan pengaruh yang signifikan terhadap citarasa, sedangakan nilai $\mathrm{pH}$, kadar air dan kekenyalan tidak signifikan. Kesimpulan yang diperoleh adalah penggunaan filler tepung terigu (berprotein tinggi) menghasilkan kualitas bakso yang baik dengan citarasa yang sangat disukai oleh panelis.
\end{abstract}

Kata Kunci: daging sapi, filler, bakso

*Korespondensi (corresponding author):

Email:meitysompie@yahoo.com

\section{ABSTRACT}

THE EFFECT OF DIFFERENT FILLER ON pH, WATER CONTENT, FLAVOR AND ELASTICITY OF BEEF MEATBALL. This research was aimed to determine the effect of different fillers on $\mathrm{pH}$, water content, flavor and elasticity of beef meatball. This study used Completely Randomized Design (CRD) with four treatments and four replicates at each treatment. The treatments were involving $15 \%$ concentration of different fillers (R) including: $\mathrm{R}_{1}=$ tapioca flour, $\mathrm{R}_{2}=$ sagu flour, $\mathrm{R}_{3}=$ corn flour, and $\mathrm{R} 4=$ wheat flour. The Variables were $\mathrm{pH}$, water content, flavor and elasticity. The mean difference was tested using BNJ Test. The results showed that the filler of each flour in beef meatball significantly affected $(\mathrm{P}<0.05)$ on flavor, but did not affect the $\mathrm{pH}$ value, water content and elasticity on the beef meatballs. It was concluded that the use of wheat flour (high protein) produced the best meatball quality of flavors, very preferred by panelists.

Key words: beef, meatball, fillers.

\section{PENDAHULUAN}

Kebutuhan gizi masyarakat dapat diperoleh dari produk hewani sebagai sumber protein seperti daging sapi yang banyak disukai masyarakat. Daging merupakan salah 
satu komoditas utama di Indonesia seiring dengan peningkatan jumlah penduduk dan kesadaran masyarakat akan pentingnya protein hewani (Harmini et al., 2011). Kebutuhan protein hewani asal ternak sesuai dengan standar kebutuhan gizi nasional setara dengan 6,0 gram/kapita/hari (Sonbait et al., 2008). Meningkatnya pengetahuan masyarakat akan menuntut suatu produk memiliki kualitas dan mutu yang baik (Khasrad dan Ningrat, 2010). Bakso dapat dibuat dari berbagai jenis daging misalnya daging sapi, kerbau, ayam, dan daging ikan. Pada umumnya masyarakat lebih menyukai bakso daging sapi, walaupun daging sapi cukup mahal. Dalam pembuatan bakso biasanya ditambahkan tepung misalnya tepung tapioka (Nullah et al., 2016). Bakso dibuat dari campuran daging tidak kurang dari $50 \%$ dan pati atau tepung, dengan bahan tambahan makanan yang diizinkan. Bakso adalah suatu produk dari daging yang digiling atau dihaluskan, dicampur dengan tepung dan bumbu serta sedikit garam, dibentuk bulat kemudian direbus. Bakso dikenal sebagai makanan jajanan yang disukai karena jenis dan harga bakso yang beranekaragam dan harga yang relatif murah sehingga dapat memenuhi selera dan daya beli semua lapisan masyarakat. Oleh karena itu perlu disediakan bahan tambahan dan bahan pengisi makanan lain yang dapat digunakan secara aman. Penambahan tepung sebagai filler bakso bertujuan untuk memperbaiki tekstur, menurunkan penyusutan akibat pemasakan dan meningkatkan elastisitas produk. Dalam penganekaragaman bahan pangan, maka filler selain tepung tapioka bisa digunakan dengan tepung yang lain seperti tepung sagu, tepung jagung dan tepung terigu (gluten, berprotein tinggi). Tepung terigu (gluten, berprotein tinggi) disukai karena mempunyai kadar gluten antara $12 \%$ - 13\%. Tepung ini diperoleh dari gandum keras (hard wheat). Tepung terigu (gluten, berprotein tinggi) merupakan hasil ekstraksi dari proses penggilingan gandum (T. sativum) yang tersusun oleh $67-70 \%$ karbohidrat, 10-14\% protein, 1-3\% lemak (Fitasari, 2009). Untuk pembuatan bakso daging sapi dengan menggunakan fiiler seperti tepung sagu, tepung jagung, dan tepung terigu (gluten, berprotein tinggi) belum banyak dilakukan penelitian sehingga informasi yang diperoleh masih kurang. Berdasarkan hal tersebut diatas, maka telah dilakukan suatu penelitian tetang penggunaan filler yang berbeda terhadap nilai $\mathrm{pH}$, kadar air, citarasa dan kekenyalan bakso daging sapi. 


\section{MATERI DAN METODE PENELITIAN}

Bahan yang digunakan adalah 1600 gram daging sapi, garam, bumbu, es batu, tepung tapioka, tepung jagung kuning, tepung sagu, tepung terigu, sodium tripolifosfat, kertas saring, kertas label, aqua dan ketimun.

Peralatan yang digunakan dalam penelitian ini terdiri dari alat-alat untuk membuat bakso yaitu penggiling daging, panci, kompor gas, serbet, alat tiris, piring, pisau, sendok, dan blender/chopper. Peralatan untuk analisa terdiri dari gelas piala, $\mathrm{pH}$ meter, timbangan analitik, thermometer, stopwatch, dan desikator.

Penelitian ini dilaksanakan melalui suatu percobaan dengan menggunakan Rancangan Acak Lengkap (RAL) terdiri dari 4 perlakuan dan 4 ulangan (Steel dan Torrie, 1995) adalah untuk variable nilai $\mathrm{pH}$ dan kadar air, dan 35 ulangan (panelis) adalah untuk citarasa dan kekenyalan.

Susunan perlakuan:

$\mathrm{R}_{1}=400 \mathrm{~g}$ daging + tepung tapioka $15 \%$

$\mathrm{R}_{2}=400 \mathrm{~g}$ daging + tepung sagu $15 \%$

$\mathrm{R}_{3}=400 \mathrm{~g}$ daging + tepung jagung $15 \%$

$\mathrm{R}_{4}=400 \mathrm{~g}$ daging + tepung terigu (gluten, berprotein tinggi) $15 \%$
Pembuatan bakso dimulai dengan pencucian daging sapi. Setelah itu dibersihkan dari jaringan ikat dan lemak, dipotong kecil-kecil dan dihancurkan dengan menggunakan alat penggiling daging kemudian dicampur masing-masing tepung 15\% (tepung tapioka, tepung jagung, tepung sagu dan tepung terigu), garam dapur 1,5\%, es batu $20 \%$, lada $0,2 \%$ dan bawang putih 0,2\%, STPP 0,75\%. Setelah itu dicampur dengan menggunakan chopper sampai adonan menjadi homogen. Adonan dibuat menjadi bulat kemudian direbus dalam air mendidih selama 10 menit atau sampai bakso mengapung. Bakso diangkat dan tiriskan sampai permukaanya kering kemudian dianalisa. Lebih jelas dapat dilihat pada Gambar 1.

Variabel yang diukur mencakup antara lain:

a. Nilai pH (Winarno dan Fardiaz, 1980)

Sampel sebanyak 10 g ditambahkan 20 $\mathrm{mL}$ aquades dan diblender selama 1 menit, lalu dituangkan kedalam gelas piala. Setelah itu diukur $\mathrm{pH}$ dengan menggunakan $\mathrm{pH}$ meter. Sebelum pH meter digunakan angka penunjuknya diatur dengan menggunakan larutan buffer $\mathrm{pH}$ 7,0. Setelah angka penunjuk pada $\mathrm{pH}$ meter stabil maka elektroda $\mathrm{pH}$ meter dalam pembacaan jarum 


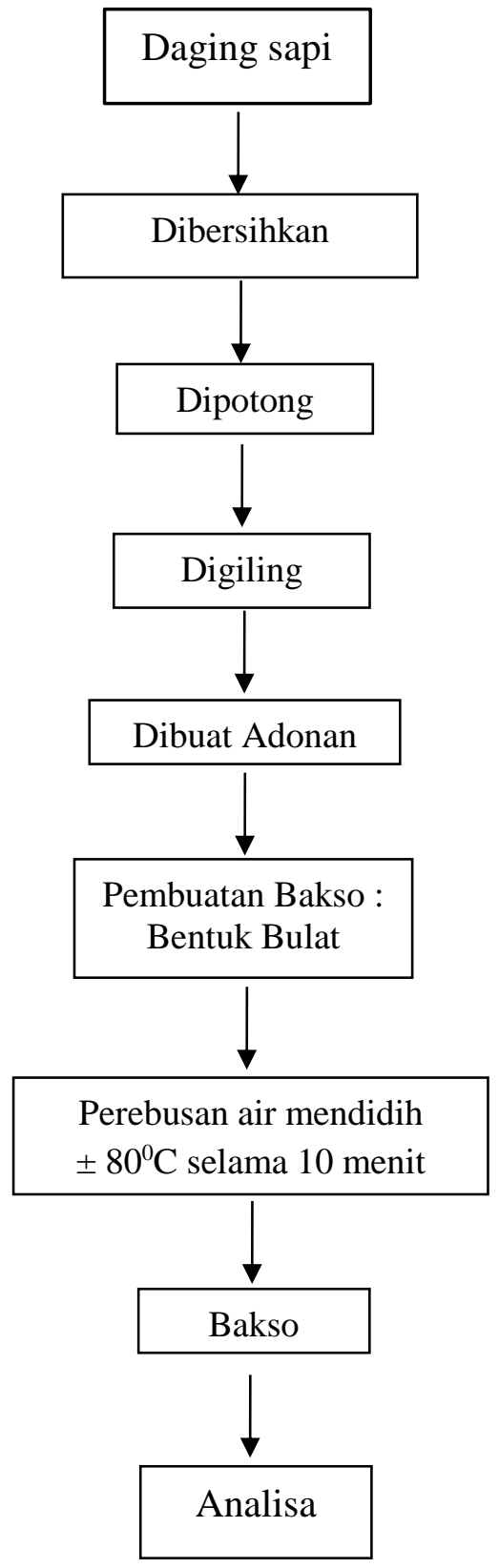

Gambar 1. Proses pembuatan bakso daging sapi

penunjuk $\mathrm{pH}$ setelah jarum skala konstan kedudukannya.

b. Kadar Air
Pemeriksaan kadar air digunakan metode pengeringan atau oven (Thermogravimetri). Menurut Legowo (2005), prosedur dan perhitungan kadar air dengan metode pengeringan oven adalah sebagai berikut : pertama-tama disiapkan cawan porselin yang telah diberi kode sesuai kode sampel, kemudian dipanaskan dalam oven dengan suhu $100-105^{\circ} \mathrm{C}$ selama \pm 1 jam, cawan porselin diambil dan dimasukan dalam desikator \pm 15 menit, kemudian cawan porselin ditimbang. Sampel sebanyak $1-2 \mathrm{~g}$ ditimbang dalam cawan porselin yang telah diketahui beratnya. Kemudian dikeringkan dalam oven dengan suhu $100-105^{\circ} \mathrm{C}$ selama 4-6 jam, setelah dioven sampel ditimbang hingga tercapai bobot konstan, jika belum konstan sampel dimasukkan kedalam oven lagi selama 1 jam, dimasukkan desikator, kemudian dilakukan penimbangan hingga tercapai bobot konstan. Bobot dianggap konstan apabla selisih penimbangan tidak melebihi 0,2 mg. Setelah mendapatkan bobot konstan kadar air dapat dihitung dengan rumus sebagai berikut:

kadar air

$=\frac{(B C+B S)-(B C+B S \text { setelah dioven })}{\mathrm{BS}} \times 100 \%$

\section{Keterangan:}

BC: Berat Cawan

BS: Berat Sampel 
c. Citarasa (Soekarto dan Hubeis, 1993)

Prosedur pengujian untuk citarasa yaitu panelis terlebih dahulu memakan mentimun dan meminum aqua untuk menetralisir indra perasa. Selanjutnya panelis mengambil sampel bakso daging sapi yang sudah disiapkan yang telah diberi kode angka untuk setiap perlakuan dan menilai tingkat rasa enak yang disukai, kemudian mengisi penilaian dalam lembar format uji.

Kriteria penilaian untuk citarasa adalah sebagai berikut:

1. Sangat tidak enak

2. Tidak enak

3. Biasa/netral

4. Enak

5. Sangat enak

6. Amat sangat enak

d. Kekenyalan (Soekarto dan Hubies, 1993)

Prosedur pengujian untuk kekenyalan yaitu panelis terlebih dahulu memakan mentimun dan meminum aqua untuk menetralisir indra perasa. Selanjutnya panelis mengambil sampel bakso daging sapi yang sudah disiapkan yang telah diberi kode angka untuk setiap perlakuan dan menilai tingkat rasa kenyal yang disukai, kemu dian mengisi penilaian dalam lembar format uji.

Kriteria penilaian untuk kekenyalan adalah sebagai berikut:

1. Sangat tidak kenyal

2. Tidak kenyal

3. Biasa/netral

4. Kenyal

5. Sangat kenyal

6. Amat sangat kenyal

\section{Analisis Data}

Data penelitian yang terdiri dari $\mathrm{pH}$, kadar air, citarasa dan kekenyalan menggunakan analisis ragam dengan Rancangan Acak Lengkap (RAL), dan apabila terdapat perbedaan rataan akan dilanjutkan dengan uji Beda Nyata Jujur (Steel dan Torrie, 1995).

\section{HASIL DAN PEMBAHASAN}

Data rataan hasil pengamatan terhadap sifat fisik nilai $\mathrm{pH}$, kadar air, citarasa, dan kekenyalan bakso daging sapi menggunakan tepung tapioka, tepung sagu, tepung jagung dan tepung terigu selama penelitian disajikan pada Tabel 1 . 
Tabel 1. Rataan bakso daging sapi menggunakan tepung tapioka, sagu, jagung dan terigu (gluten, berprotein tinggi) terhadap sifat fisik nilai $\mathrm{pH}$, kadar air, citarasa dan kekenyalan.

\begin{tabular}{lllll}
\hline Variabel & \multicolumn{4}{c}{ Jenis Tepung } \\
\cline { 2 - 5 } & $\begin{array}{l}\text { Tepung } \\
\text { Tapioka }\end{array}$ & Tepung & Tepung & Tepung \\
& 6,30 & 6,30 & 6,30 & 6,40 \\
\hline Nilai $\mathrm{pH}$ & 66,88 & 68,39 & 67,94 & 67,05 \\
Kadar air $(\%)$ & $4,82^{\mathrm{a}}$ & $4,54^{\mathrm{a}}$ & $4,20^{\mathrm{b}}$ & $5,05^{\mathrm{c}}$ \\
Citarasa & 4,74 & 4,34 & 4,51 & 4,60 \\
Kekenyalan & & & Jagung & Terigu \\
\hline
\end{tabular}

Keterangan: Superskrip yang berbeda pada baris yang sama menunjukan perbedaan yang nyata

\section{Nilai pH}

Nilai pH merupakan konsentrasi ion hidrogen yang berdisosiasi dalam larutan. Tabel 1 menunjukkan bahwa perlakuan jenis tepung memberikan pengaruh berbeda tidak nyata $(\mathrm{P}>0,05)$ terhadap nilai $\mathrm{pH}$ bakso daging sapi. Nilai $\mathrm{pH}$ penelitian ini berkisar antara 6,30-6,40. Nilai ini masih dalam kisaran normal sesuai hasil penelitian dari Nullah et al. (2016) yang menggunakan bahan filler lokal tepung sagu, ubi kayu, dan talas.

\section{Kadar Air}

Hasil analisis sidik ragam menunjukkan bahwa perlakuan jenis tepung memberikan tidak memberikan pengaruh yang nyata terhadap kadar air bakso. Pada Tabel 1 menunjukan bahwa nilai rataan kadar air berkisar antara 66,88\% - 68,39\%. Hasil nilai kadar air pada penelitian ini sudah memenuhi standar kadar air yang ditetapkan oleh SNI (1995).

\section{Citarasa}

Hasil analisis ragam (Tabel 1) menunjukkan bahwa perlakuan jenis tepung memberikan pengaruh yang berbeda nyata $(\mathrm{P}<0,05)$ terhadap citarasa bakso daging sapi. Data rataan hasil penelitian menunjukkan bahwa nilai citarasa bakso berada pada kisaran nilai 4,20 (enak) sampai 5,05 (sangat enak). Hasil uji BNJ menunjukkan bahwa bakso yang menggunakan tepung terigu (R4) memberikan pengaruh citarasa yang sama terhadap bakso dengan filler tepung tapioka (R1) dan tepung sagu (R2) tetapi memberikan pengaruh yang berbeda nyata dengan bakso yang menggunakan tepung jagung (R3). Keistimewaan tepung terigu jika dibandingkan dengan tepung lainnya 
adalah kemampuannya dalam membentuk gluten pada adonan ini menyebabkan elastis atau tidak mudah hancur pada proses pencetakan dan pemasakan (Matz, 1972). Tepung terigu biasanya dikaitkan dengan gluten yang terbentuk dari kandungan protein dalam tepung. Semakin tinggi kadar protein dalam tepung, semakin tinggi pula gluten yang terbentuk saat pengolahan, karena gluten menentukan tingkat elastisitas dan kekenyalan suatu produk (Suseno et al., 2007).

\section{Kekenyalan}

Hasil analisis ragam (Tabel 1) menunjukkan bahwa perlakuan jenis tepung memberikan pengaruh yang berbeda tidak nyata $(\mathrm{P}>0,05)$ terhadap kekenyalan bakso daging sapi. Dengan kata lain penggunaan berbagai jenis tepung memberikan nilai kekenyalan bakso yang sama. Selanjutnya berdasarkan Tabel 1, nilai rataan kekenyalan tertinggi terdapat pada bakso yang menggunakan $15 \%$ tepung tapioka (R1) yaitu pada kisaran 4,74 (sangat kenyal) dan terrendah terdapat pada bakso yang menggunakan $15 \%$ tepung sagu (R2) yaitu pada kisaran 4,34 (kenyal). Nilai kekenyalan ini dipengaruhi oleh kandungan amilopektin yang tinggi dalam tepung tapioka sehingga dapat membentuk produk bakso yang kenyal (Montolalu et al., 2013).

\section{KESIMPULAN}

Penggunaan filler tepung terigu (gluten, berprotein tinggi) menghasilkan citarasa yang sangat disukai oleh panelis.

\section{DAFTAR PUSTAKA}

Buckle, K., R.A. Edward, G.H.F. Lect, dan M. Wooton. 1987. Ilmu Pangan. Universitas Indonesia. Jakarta.

Fitasari, E. 2009. Pengaruh tingkat penambahan tepung terigu terhadap kadar air, kadar lemak, kadar protein, mikrostruktur, dan mutu organoleptik keju gouda olahan. Jurnal Ilmu dan Teknologi Hasil Ternak. 4 (2): 17-29.

Harmini., R.W. Asmarantaka, J. Atmakusuma. 2011. Model dinamis sistem ketersediaan daging sapi nasional. J Ekonomi Pembangunan 12(1): 128- 146.

Hatta, M dan E. Murpiningrum. 2012. Kualitas bakso daging sapi dengan penambahan garam (Nacl) dan fosfat (Sodium Tripolifosfat/Stpp) pada level dan waktu yang berbeda. JITP 2(1): 30-38.

Khasrad dan R.W.S Ningrat. 2010. Improving carcass quality of indigenous cattle of West Sumatera fed local feed resources. Pakistan. J of Nutrition 9(8): 822-826. 
Legowo, A.M., Nurwantoro dan Sutaryo. 2005. Analisis Pangan. Badan Penerbit Universitas Diponegoro, Semarang.

Matz, S.A. 1972. Bakery Technology and Engineering. Second edition, The AVI Publishing Co, Inc, Westport, Connecticut.

Montolalu, S., N. Lontaan, S. Sakul, A.Dp. Mirah. 2013. Sifat Fisiko Kimia dan Mutu Organoleptik Bakso Broiler Dengan Menggunakan Tepung Ubi Jalar. Jurnal Zootek 32 (5) 1-13

Nullah, L.M., H. Hafid, A. Indi. 2016. Efek bahan filler lokal terhadap kualitas fisik dan kimia bakso ayam petelur afkir. JITRO 3(2): 14 - 20.

Soekarto, S.T. dan M. Hubeis. 1993. Metodologi Penelitian Indrawi. Petunjuk Laboratorium Pusat Antar Universitas Pangan dan Gizi. IPB. Bogor.
Sonbait, L.Y., H. Monim, D. Woran. 2008. Preferensi konsumen terhadap produk olahan daging sapi di Kota Sorong. J. Ilmu Peternakan 3(1): 87- 93.

Standar Nasional Indonesia. 1995. Standar Mutu Bakso Daging. SNI 01-38181995. Dewan Standarisasi Nasional, Jakarta

Steel, R.G. dan J.H. Torrie. 1995. Prinsip dan Prosedur Statistik. Gramedia Pustaka Utama. Jakarta.

Suseno, T.I.P., S. Surjoseputro, I.M. Fransiska. 2007. Pengaruh jenis bagian daging babi dan penambahan tepung terigu terhadap sifat fisikomiawi pork nugget. Jurnal Teknologi Pangan dan Gizi. 6(2): 1522.

Winarno, F.G. dan D. Fardiaz. 1980. Pengantar Teknologi Hasil Pertanian. Faperta.IPB. Bogor. 